\title{
Microbiological Quality Assessment of Cereal Based Food 'Pitha' On Retail Sale in the Street Of Dhaka City, Bangladesh
}

\author{
Fahmida Binte Atique ${ }^{1 *}$, Kazi Tahsin Ahmed ${ }^{1}$, and Fauzia Begum ${ }^{2}$ \\ ${ }^{1}$ Department of Biochemistry and Microbiology, North South University, Dhaka, Bangladesh, ${ }^{2}$ Food \\ Microbiology Lab, Institute of Food Science and Technology (IFST), Bangladesh Council of Scientific and \\ Industrial Research, (BCSIR), Dhaka.
}

\begin{abstract}
Pitha' is one of the most popular traditional foods made up from various kinds of cereal grains like rice, wheat's, flours etc. The microbiological quality of pitha on retail sale in the street of Dhaka city was studied with thirty six different samples by detecting the range of total viable count (TVC) of bacteria, indicator microorganisms, such as Escherichia coli, Enterobacteriaceae and the common food pathogens Staphylococcus aureus, Bacillus cereus., Salmonella Spp. and Pseudomonas spp. In our study, the majority (67.5\%) of the microbial contaminants were gram negative rods. The TVC of bacteria was ranged from $\left(9.0 \times 10^{3}\right)$ cfulg to $\left(1.2 \times 10^{6}\right) \mathrm{cfu} / \mathrm{g}$. Total coliform, fecal coliform and E. coli were detected from $30.56 \%, 22.2 \%$ and $13.8 \%$ of the samples respectively indicating unsatisfactory results. For Salmonella spp. $16.6 \%$ of the samples were unable to reach the acceptability levels. Besides, according to the ICMSF (International Commission on Microbiological Specifications for food), in terms of Pseudomonas spp. 33.3\%, for Staphylococcus aureus $12.2 \%$ and for Bacillus cereus $11.1 \%$ of the samples were not suitable for the consumption. All these phenomena indicate poor hygiene practices. This study emphasizes the need to improve production hygiene.
\end{abstract}

Key Words: Pitha, Microbial contamination, Coliform, Indicator organisms, Retail sale, Street market.

\section{Introduction}

Pitha- a kind of rice cuisine produced according to the ancient manufacturing techniques. The major ingredients of pitha are rice, wheat's or flours, molasses or sugar, coconut and oil etc. Though pitha's are usually homemade food but now-a-days they are commercially sold by the vendors and hawkers especially in streets, portable stalls and other similar public places which are easily accessible to the general people. As all scale of people every day consumes pitha so, it is important to check the quality of this food to avoid unwanted transmission of any food borne infections.

Most of the cereals or cereal based products contain a restrictive water activity that's why it is difficult to prevent the growth of microorganisms. Pitha's can be contaminated with various types of bacteria and fungi during processing, handling, production or preservation. Between productions to storage, foods come in contact with different people which frequently lead to the contamination. The raw materials of pitha and processed pitha's are sometimes held on refrigerator, continuous opening of the freezer door can also contaminate these foods. Water is one of the main ingredients for the processing of pitha. Improperly treated water can contain pathogenic and spoilage microorganisms. The water is often used directly without any treatment after collection from the rivers. The most dangerous form of water pollution occurs when fecal contaminants enter to the water and results in high prevalence of water borne diseases- diarrhea, cholera, dysentery etc. According to the report of BRAC in 2008, every year more than one hundred thousand under-five children die due to diarrhoea related diseases in Bangladesh [1]. Moreover, there is hardly any quality control methods apply to check water for contaminants and pathogen [2]. Thus, water quality can greatly influence microbial quality of these kinds of food. Besides water, sugar and molasses are other important ingredients in the preparation of pitha. The microbial load may be high in raw juice expressed from the sugarcane if the processing is not prompt. During the refining of the raw sugar, contamination may come from the equipment's [3]. In addition, pitha's are typically held at room temperature before they sold which can dramatically reduce their quality. The packaging material may also be a source of contamination as almost no microbial quality assessment is done on packaging materials.

In order to prevent all these contaminations different strategies need to be taken like- appropriate temperature should be maintained during the transportation of food; the storage conditions should be proper after processing and before shipment of the processed food and finally cereal grains should not processed to reduce their natural flora, if enough moisture is added, bacterial strains will be ready to grow [4]. 


\section{Materials and Methods}

\subsection{Sample Collection}

The whole experiment was carried out at the Food Microbiology Section, Institute of Food Science and Technology (IFST), Bangladesh Council of Scientific and Industrial Research (BCSIR), Dhaka from December 18, 2008 to July 02, 2009. A total thirty six samples were collected from the roadside shops and open places from eighteen different areas of the Dhaka city. During sample collection tightly air sealed packets were used. The sample packets were marked properly and transported to laboratory as soon as possible. Experiments were carried out within 1-8 hours after collecting the samples. All the media used for the microbial assessment, collected from Hi media and Oxoid.

\subsection{Enumeration of Total Viable Count (TVC)}

For each of the thirty six samples, $10 \mathrm{gm}$. of sample was added to $90 \mathrm{ml}$ of sterile Ringer's solution and homogenized for one minute in a stomacher mixer. $1 \mathrm{ml}$ of first dilution was transferred with a sterile pipette to the tube containing $9 \mathrm{ml}$ of Ringer Solution which made $10^{-1}$ dilution. In such a way dilutions up to $10^{-6}$ were made. All the plates were then incubated at $37^{\circ} \mathrm{C}$ for 24 hours and screened for the presence of discrete colonies. In case of coliform bacteria, each of the three tubes of Lactose Tryptose Broth (containing inverted Durham tubes) was inoculated with $1.0 \mathrm{ml}$ of the food homogenate (1 in 10). The same operation from the first $(1 \mathrm{in} 100 \mathrm{~m})$ and the second $(1 \mathrm{in} 1000 \mathrm{ml})$ dilution tubes were carried out with sterile pipette for each dilution. The prepared LTB tubes were incubated at $37^{\circ} \mathrm{C}$ for 24 to 48 hours. Tubes showing gas production after 24 hours were recorded. Negative tubes were re inoculated for further 24 hours. Then tubes showing gas production were recorded. For better and authentic bacterial count, both spread and pour plate techniques were followed. TVC of the bacterial isolates were determined by multiplying colony numbers with dilution factor and reported as cfu/ml.

\subsection{Cultural Characterization and Biochemical Studies of the Sample Microflora}

Cultural characteristics of the bacterial isolates were studied by Gram staining method using freshly prepared reagents to identify whether the isolates were Gram (+) ve or Gram (-) ve. The shape, size, form, texture, pigment production of isolated colonies were observed. Gram staining procedure was followed for the different types of colonies obtained from the selective and differential media. Biochemical characteristics of the bacterial isolates were analyzed by different tests including, Oxidase test, Catalase test, Indole production test, Methyl Red (MR) test, Voges- proscauer (VP) test, Motility test, Citrate utilization test, and Carbohydrate fermentation test according to the standard method of Cheesbrough [5].

\section{Results And Discussion}

All the samples were contaminated with different types of bacteria. The highest bacterial count was $\left(1.2 \times 10^{6}\right) \mathrm{cfu} / \mathrm{gm}$. and the lowest count was $\left(9.0 \times 10^{3}\right) \mathrm{cfu} / \mathrm{gm}$. In our study, both gram positive and gram negative bacteria were isolated frequently but the majority (67.5\%) of the microbial contaminants observed on the sample was Gram negative rods. Staphylococcus spp. was the highest abundant organism (26 in 36, 72.2\%) while Escherichia coli was the lowest (3 in 36, 8.3\%). Frequency of the bacterial isolates is presented in table-1.

Table- 1: Frequency distribution of microorganisms.

\begin{tabular}{|c|l|c|c|}
\hline \multirow{3}{*}{ Total sample } & \multicolumn{1}{|c|}{ Organism } & Number of positive sample & Percentages (\%) \\
\hline \multirow{4}{*}{36} & Total coliform & 11 & 30.5 \\
\cline { 2 - 4 } & Fecal coliform & 08 & 22.2 \\
\cline { 2 - 4 } & Escherichia coli & 05 & 13.8 \\
\cline { 2 - 4 } & Staphylococcus spp. & 26 & 72.2 \\
\cline { 2 - 4 } & Staphylococcus aureus & 08 & 22.2 \\
\cline { 2 - 4 } & Pseudomonas spp. & 12 & 33.3 \\
\cline { 2 - 4 } & Salmonella spp. & 06 & 16.6 \\
\cline { 2 - 4 } & Bacillus cereus & 04 & 11.1 \\
\hline
\end{tabular}


Food born infections including diarrhoea, dysentery, typhoid, parasitic worm infection etc are major causes of mortality and morbidity in Bangladesh. Coliforms like E. coli are the direct indicator of fecal contamination [6]. Although most of the strains of $E$. coli usually not regarded as pathogen but when they become an opportunistic pathogen, can cause infection to the immunocompromised hosts [7]. In our study coliforms as a primary pathogen, were determined by the inoculation on Lauryl Tryptose Broth (LTB) $\rightarrow$ Brilliant Green Bile Broth (BGBB) $\rightarrow$ EMB agar. After 24 hours of incubation at $37^{\circ} \mathrm{C}$ EMB plates were observed for the presence or absence of green metallic sheen. The highest coliform count was recorded as $23 \mathrm{MPN} / \mathrm{g}$ on average while the lowest count was 4.6 MPN/g among the samples analyzed. In addition, the highest fecal coliform count was 9.4 $\mathrm{MPN} / \mathrm{g}$ and the lowest count was recorded as $4.1 \mathrm{MPN} / \mathrm{g}$. A total five isolates of $E$. coli from the confirmed test on EMB agar were subjected to further biochemical analysis (Table-2).

Table-2: Summary of the biochemical tests of $E$. coli

\begin{tabular}{|c|c|c|c|c|c|c|c|c|c|c|c|}
\hline \multirow{2}{*}{$\begin{array}{c}\text { Sample } \\
\text { ID }\end{array}$} & \multirow{2}{*}{$\begin{array}{c}\text { Catalase } \\
\text { Test }\end{array}$} & \multirow{2}{*}{$\begin{array}{c}\text { Oxidase } \\
\text { Test }\end{array}$} & \multirow{2}{*}{$\begin{array}{c}\text { Motility } \\
\text { Test }\end{array}$} & \multicolumn{4}{|c|}{ IMViC Test } & \multicolumn{4}{|c|}{ Fermentation Test } \\
\hline & & & & Indole & $\begin{array}{c}\text { Methyl } \\
\text { Red }\end{array}$ & $\begin{array}{l}\text { Voges- } \\
\text { Proskeur }\end{array}$ & $\begin{array}{c}\text { Citrate } \\
\text { Utilization }\end{array}$ & Lactose & Sucrose & Glucose & Mannito \\
\hline S-5 & $(+)$ & $(-)$ & $(+)$ & $(-)$ & $(+)$ & $(+)$ & $(-)$ & $(+)$ & $(+)$ & $(+)$ & $(+)$ \\
\hline S-8 & $(+)$ & $(-)$ & $(+)$ & $(-)$ & $(+)$ & $(-)$ & $(+)$ & $(+)$ & $(+)$ & $(+)$ & $(+)$ \\
\hline S-9 & $(+)$ & $(-)$ & $(+)$ & $(+)$ & $(+)$ & $(-)$ & $(+)$ & $(+)$ & $(+)$ & $(+)$ & $(+)$ \\
\hline S-17 & $(+)$ & $(-)$ & $(+)$ & $(-)$ & $(+)$ & $(-)$ & $(-)$ & $(+)$ & $(+)$ & $(+)$ & $(+)$ \\
\hline S-26 & $(+)$ & $(-)$ & $(+)$ & $(-)$ & $(+)$ & $(-)$ & $(-)$ & $(+)$ & $(+)$ & $(+)$ & $(+)$ \\
\hline
\end{tabular}

Salmonella are considered as a group of food poisoning organisms which have the potentiality to produce biofilm on the surface of food [8]. Human beings and animals are directly or indirectly the source of contamination with Salmonellae spp. This organism may be transmitted by water and food [9]. For the detection of Salmonella spp., Lactose Broth (LB) $\rightarrow$ Selenite Broth (SB) $\rightarrow$ Bismuth sulfate agar (BSA) were used. As a confirmatory test Triple sugar Iron (TSI) and Urease tests were performed. But only $16.6 \%$ of the samples showed growth in the media.

Staphylococcus aureus is another most common food poisoning bacterium found on the skin and respiratory tract of nearly all humans and often serve as an opportunistic pathogen. Staphylococcus aureus is frequently associated with food poisoning because this organism produces several heat-stable protein enterotoxins. If food that contain toxin is ingested, gastroenteritis characterized by nausea, vomiting and diarrhea occurs within 1-6 hours [10]. That's why their presence in food or food processing equipment indicates poor hygiene quality [11]. For the detection of total Staphylococcal count and the count of Staphylococcus aureus-Staphylococcus 110 medium and Baired Parker Agar (BPA) medium were used. The range of total of Staphylococcus spp. was (3.5 $\left.\mathrm{x} 10^{2}\right) \mathrm{cfu} / \mathrm{ml}$ to $\left(2.3 \times 10^{4}\right) \mathrm{cfu} / \mathrm{ml}$ in which Staphylococcus aureus was present in $12.2 \%$ of the samples.

The present investigation was also carried out for the isolation and identification of Bacillus cereus which was recorded only $11.1 \%$ of the samples. B. cereus is a soil organism and unavoidable contaminants of grains and flours. In cooked food unsatisfactory level of Bacillus cereus can occur due to the inadequate temperature control. They might be controlled or reduced by cleaning the grains but it cannot be totally eliminated [12].

In case of Pseudomonas spp., after the primary identification by microscopic and biochemical characterization, the suspected organism was inoculated into the cetrimide agar and blood agar medium. On cetrimide agar plate the bacteria showed bright yellowish green colony which also showed fluorescence under exposure to UV ray. On the other hand, in blood agar plate bacteria showed $\beta$-hemolytic zone around the colony.

The contamination level (Table-3) was determined because of the safe- guard of public health according to the ICMSF (International Commission on Microbiological Specifications for food), 2006 based on the presence of indicators of poor hygiene practice. 
Table-3: Assessment of the quality of the samples on the basis of contamination.

\begin{tabular}{|c|c|c|c|}
\hline \multirow{2}{*}{ Types of microorganisms } & \multicolumn{3}{|c|}{ Microbial Quality } \\
\hline & Satisfactory & Marginal & Unsatisfactory \\
\hline Total viable counts & $\begin{array}{c}84.40 \% \\
<10^{6} \mathrm{cfu} / \mathrm{g}\end{array}$ & $\begin{array}{c}5.20 \% \\
<10^{5} \mathrm{cfu} / \mathrm{g}\end{array}$ & $\begin{array}{c}10.20 \% \\
<10^{7} \mathrm{cfu} / \mathrm{g}\end{array}$ \\
\hline E. coli & $\begin{array}{l}79.50 \% \\
<3 \mathrm{cfu} / \mathrm{g}\end{array}$ & $\begin{array}{c}6.7 \% \\
3-100 \%\end{array}$ & $\begin{array}{c}13.8 \% \\
\geq 100 \mathrm{cfu} / \mathrm{g}\end{array}$ \\
\hline Bacillus cereus & $\begin{array}{c}88.10 \% \\
<10^{2} \mathrm{cfu} / \mathrm{g}\end{array}$ & $\begin{array}{c}4.1 \% \\
10^{2}-10^{3} \mathrm{cfu} / \mathrm{g}\end{array}$ & $\begin{array}{c}7.80 \% \\
10^{3}-10^{4} \mathrm{cfu} / \mathrm{g}\end{array}$ \\
\hline Staphylococcus aureus & $\begin{array}{c}85.2 \% \\
<10^{2} \mathrm{cfu} / \mathrm{g} \\
\end{array}$ & $\begin{array}{c}2.6 \% \\
10^{2}-10^{3} \mathrm{cfu} / \mathrm{g} \\
\end{array}$ & $\begin{array}{c}12.2 \% \\
10^{3}-10^{4} \mathrm{cfu} / \mathrm{g}\end{array}$ \\
\hline Salmonella spp. & $\begin{array}{c}83.40 \% \\
\text { nil }\end{array}$ & nil & $16.60 \%$ \\
\hline
\end{tabular}

\section{Conclusion}

There are huge prospects of pitha in Bangladesh. It can play an important role in the present economy of the country. Street food micro-industries are vital for the economic planning and development of many towns because they require relatively simple skills, basic facilities and small amount of capitals. It can also play a role in eradicating malnutrition. Therefore, due to the public health concerns, it is very important to check the microbiological quality of this street food to avoid food born infections. Therefore, our study demonstrated that more than half of the samples supposedly made up from various kinds of cereals, sale in the street shops or roadside open places of Dhaka city were satisfactory or borderline of the microbiological quality. In conclusion, it is essential for the people who handle the preparation and marketing of pitha, to be properly trained on safe food handling under special care by the concerned enterprises and the governmental authorities.

\section{References}

[1] BRAC (2008). WASH Programme of BRAC: Towards attaining the MDG targets- baseline findings, Research and Evaluation Division, BRAC, Dhaka Bangladesh. Available at: www.bracreseacrh.org.

[2] F. R. Pinu, S. Yeasmin, L. Bari and M. M. Rahman, Microbiological conditions of frozen shrimp in different food market of Dhaka City. Food Sci. Technol. Res, (13), 2007, 362-365.

[3] W. C. Frazier and D. C. Westhoff, Contamination, Preservation and Spoilage of sugars and sugar Products, Food Microbiology, (Singapore: McGraw-Hill Book Co., 2007). pp. 187

[4] W. C. Frazier and D. C. Westhoff, Contamination, Preservation and Spoilage of Cereals and Cereal Products, Food Microbiology, (Singapore: McGraw-Hill Book Co., 2007). pp. 179

[5] M. Cheesbrough, Medical Laboratory Manual for Tropical Countries, Microbiology, Vol. II. Cambridge: University Press. ISBN 075060578X, PP. 58-69, 1984.

[6] A. A. Salyers \& D. D. Whitt. Bacterial pathogenesis: a molecular approach, 2nd ed. (ASM Press, Washington DC, USA, 2002).

[7] P. S. Brachman and E. Abrutyn, Bacterial Infections of Humans: Epidemiology and Control,( New York: Springer, 2009).

[8] B. Joseph, S. K. Otta, Indrani Karunasagar, and I. Karunasagar, Biofilm formation by Salmonella spp. on food contact surfaces and their sensitivity to sanitizers, International Journal of Food Microbiology, (64), 2001, 367-372

[9] L. P. Forshell and M. Wierup, Salmonella Contamination: a significant challenge to the global marketing of animal food products, Rev. Sci. tech. off. Int. Epiz., 25 (2), 2006, 541-554.

[10] M. T. Madigan, J. M. Martiko and J. Parker, Brock Biology of Microorganisms, $10^{\text {th }}$ ed. (Pearson Education, Inc., 2003)

[11] M. R. Adams and M. O. Moss, Bacterial Agents of Foodborne Illness, Food Microbiology, (New Delhi: New Age International Private Limited, 1995), pp.205.

[12] ICMSF (International Commission on Microbial Specifications for Foods, Microorganisms in Foods. 4. Application of the Hazard analysis Critical Control Point (HACCP) system to ensure microbiological safety and quality, (Blackwell Scientific Publications, 1986). 